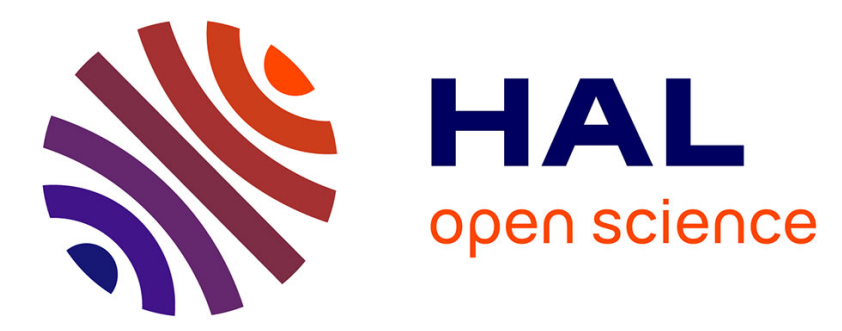

\title{
Frequency and characteristics of pruritus in patients with monoclonal gammopathy: a case-control study
}

Cécile Devergne, Hélène Kerspern, F. Poizeau, J.R. Eveillard, J.L. Carré, Laurent Misery, C. Le Gall-ianotto, E. Brenaut

\section{- To cite this version:}

Cécile Devergne, Hélène Kerspern, F. Poizeau, J.R. Eveillard, J.L. Carré, et al.. Frequency and characteristics of pruritus in patients with monoclonal gammopathy: a case-control study. Journal of the European Academy of Dermatology and Venereology, 2020, 34 (12), 10.1111/jdv.16743 . hal03370713

\section{HAL Id: hal-03370713 \\ https://hal.science/hal-03370713}

Submitted on 20 Dec 2021

HAL is a multi-disciplinary open access archive for the deposit and dissemination of scientific research documents, whether they are published or not. The documents may come from teaching and research institutions in France or abroad, or from public or private research centers.
L'archive ouverte pluridisciplinaire HAL, est destinée au dépôt et à la diffusion de documents scientifiques de niveau recherche, publiés ou non, émanant des établissements d'enseignement et de recherche français ou étrangers, des laboratoires publics ou privés. 
archives-ouvertes

\section{Frequency and characteristics of pruritus in patients with monoclonal gammopathy: a case-control study}

C Devergne, Hélène Kerspern, F. Poizeau, J. R. Eveillard, J. L. Carre, Laurent Misery, Christelle Le Gall-Ianotto, E Brenaut

\section{To cite this version:}

C Devergne, Hélène Kerspern, F. Poizeau, J. R. Eveillard, J. L. Carre, et al.. Frequency and characteristics of pruritus in patients with monoclonal gammopathy: a case-control study. Journal of the European Academy of Dermatology and Venereology, Wiley, 2020, 34 (12), 10.1111/jdv.16743 . hal-02890960

\section{HAL Id: hal-02890960 \\ https://hal.archives-ouvertes.fr/hal-02890960}

Submitted on 16 Jul 2020

HAL is a multi-disciplinary open access archive for the deposit and dissemination of scientific research documents, whether they are published or not. The documents may come from teaching and research institutions in France or abroad, or from public or private research centers.
L'archive ouverte pluridisciplinaire HAL, est destinée au dépôt et à la diffusion de documents scientifiques de niveau recherche, publiés ou non, émanant des établissements d'enseignement et de recherche français ou étrangers, des laboratoires publics ou privés. 
MISS CÉCILE DEVERGNE (Orcid ID : 0000-0002-1817-7539)

PROF. LAURENT MISERY (Orcid ID : 0000-0001-8088-7059)

DR. CHRISTELLE IANOTTO (Orcid ID : 0000-0003-0158-2850)

DR. EMILIE BRENAUT (Orcid ID : 0000-0002-0170-5083)

Article type : Letter to Editor

Letter to the Editor

Frequency and characteristics of pruritus in patients with monoclonal gammopathy: a casecontrol study

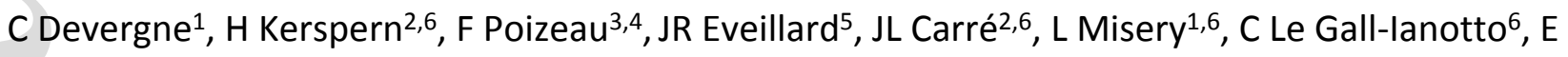
Brenaut ${ }^{1,6}$

1. Department of Dermatology, Brest University Hospital, Brest, France

2. Department of Biochemistry and Pharmaco-Toxicology, Brest University Hospital, Brest, France.

3. EA 7449 REPERES (Pharmacoepidemiology and Health Services Research), Rennes 1 University, Rennes, France

4. Department of Dermatology, Rennes University Hospital, Rennes, France

5. Department of Haematology, Brest University Hospital, Brest, France

6. Univ Brest, LIEN, F-29200 Brest, France 
Corresponding author: Emilie Brenaut, Department of Dermatology, University Hospital, 29609

Brest, France (tel: +33 2982233 15; fax: +33 2982233 82; e-mail: emilie.brenaut@chu-brest.fr)

Funding sources: This article has no funding source.

Conflicts of interest: None declared.

Manuscript word count: 616

References: 14

Figures: 0

Tables: 2

Keywords: pruritus, itch, monoclonal gammopathy, monoclonal gammopathy of undetermined significance, multiple myeloma, Waldenström's macroglobulinemia 


\section{Dear Editor,}

Chronic pruritus (CP) is a frequent symptom in many skin and systemic diseases(1), including haematological malignancies. It is described in $30 \%$ of Hodgkin lymphoma patients and in patients with myeloproliferative disorders, particularly in polycythaemia vera $(2,3)$. Serum protein electrophoresis (SPEP) is recommended in laboratory screening for $\mathrm{CP}(4)$. However, the literature about pruritus in monoclonal gammapathies (MGs) is scarce(5-7). The aim of this study was to determine the frequency and clinical characteristics of pruritus in patients with MGs in comparison to controls with normal SPEP results.

Cases and controls were selected on SPEP performed at the University Hospital of Brest between 2014 and 2018. The inclusion criteria for cases were to have a monoclonal spike of at least $15 \mathrm{~g} / \mathrm{L}$ for IgG, $10 \mathrm{~g} / \mathrm{L}$ for $\operatorname{lgA}$ and $5 \mathrm{~g} / \mathrm{L}$ for $\operatorname{lgM}$ (rates choosen because they are associated with higher risk of multiple myeloma (MM), Waldenström's macroglobulinemia (WM) and monoclonal gammopathy of clinical significance $(8,9))$. Controls had qualitative and quantitative normal SPEP results. Cases and controls were matched for the year of birth and sex. Patients with another haematological disease producing a monoclonal protein were excluded.

A questionnaire was sent out by post to patients, asking them if they suffered from pruritus. If yes, they answered to the Brest Questionnaire $(10,11)$, the 5-D Itch Scale(12) and the ItchyQoL questionnaire(13). The study protocol was approved by a Jurisdictional Ethics Committee. The trial was registered on ClinicalTrials.gov (NCT03832140).

One hundred forty-one cases and 141 controls answered the questionnaire with a respective response rate of $48 \%$ and $50 \%$. The characteristics of patients with an MG are presented in Table I. For controls, SPEP was prescribed in various conditions: stroke (41.8\%), inflammatory rheumatism (10.6\%), pre-biotherapy check-up (7.1\%), dyspnoea (6.4\%), bone pain (5\%), anaemia (2.9\%), and tumours (2.9\%). CP without any skin disease was present in 32 cases $(22.7 \%)$ and in 12 controls (8.5\%). The difference was significant with an OR of 2.46 [1.14 - 5.32] ( $p=0.023)$. Only $20 \%$ of cases with CP had consulted a dermatologist for their pruritus. CP was present for a few years for $72 \%$ of patients with MGs, a few months for $24 \%$ and a few weeks for $4 \%$. Most cases (48.3\%) had started experiencing pruritus after the diagnosis of their gammopathy, $31 \%$ had started experiencing pruritus before the diagnosis, and $20.7 \%$ had started experiencing pruritus at the same time as the diagnosis. Pruritus was triggered by contact with water in only 4 cases 
(12.9\%). The most frequently reported associated symptoms were stinging (45.1\%) and burning (38.8\%). The mean 5-D Itch Scale score was $11.0 \pm 5.9$ (range 6 to 21) for cases. The intensity of pruritus was mild for $24.1 \%$ of cases, moderate for $6.9 \%$ and severe for $65.5 \%$. The mean ItchyQol score was $38.7 \pm 18.2$ (range 22 to 73) for cases. Univariate and multivariate logistic regression analyses were performed to identify factors associated with the presence of pruritus in MGs (Table II). The only association found was with MM, which was less associated with CP than MG of undetermined significance (MGUS) and WM. No association was found between pruritus and monoclonal protein levels in MM (OR 0.97 [0.90-1.03), WM (OR 1.00 [0.93-1.06]) or MGUS (OR 1.01 [0.88-1.15]).

Our study demonstrated a significant association between MGs and pruritus. It is not an aquagenic pruritus, contrary to myeloproliferative disorders(2), which suggests different pathophysiological mechanisms. The impairment in the quality of life evaluated by the ItchyQol showed the same impairment as in patients with polycythaemia vera (37.3)(3) but a lower impairment than in haemodialysis patients $(48.4)(14)$.

To conclude, our study highlighted that $\mathrm{CP}$ is 2.5 times more frequent in patients with MGs than in controls. Thus, SPEP is useful in the check-up to find the aetiology of unexplained CP. 


\section{REFERENCES}

1. Ständer S, Weisshaar E, Mettang T, et al. Clinical classification of itch: a position paper of the International Forum for the Study of Itch. Acta Derm Venereol. 2007;87(4):291-4.

2. Le Gall-lanotto C, Brenaut E, Gouillou M, et al. Clinical characteristics of aquagenic pruritus in patients with myeloproliferative neoplasms. Br J Dermatol. 2017;176(1):255-8.

3. Lelonek E, Matusiak $Ł$, Wróbel T, Szepietowski JC. Aquagenic Pruritus in Polycythemia Vera: Clinical Characteristics. Acta Derm Venereol. 2018;98(5):496-500.

4. Weisshaar E, Szepietowski JC, Dalgard FJ, et al. European S2k Guideline on Chronic Pruritus. Acta Derm Venereol. 2019;99(5):469-506.

5. Zelicovici Z, Lahav M, Cahane P. Pruritus as a presentation of myelomatosis. $\mathrm{Br} \mathrm{Med} \mathrm{J.}$ 1977;2(6095):1154.

6. Erskine JG, Rowan RM, Alexander JO, Sekoni GA. Pruritus as a presentation of myelomatosis. Br Med J. 1977;1(6062):687-8.

7. Woo YR, Jung YJ, Kim JS, et al. Cutaneous comorbidities in patients with multiple myeloma. Medicine (Baltimore) [Internet]. 2018;97(43).

8. Kyle RA, Durie BGM, Rajkumar SV, et al. Monoclonal gammopathy of undetermined significance (MGUS) and smoldering (asymptomatic) multiple myeloma: IMWG consensus perspectives risk factors for progression and guidelines for monitoring and management. Leukemia. 2010;24(6):1121-7.

9. Fermand J-P, Bridoux F, Dispenzieri A, et al. Monoclonal gammopathy of clinical significance: a novel concept with therapeutic implications. Blood. 2018;132(14):1478-85.

10. Brenaut E, Garlantezec R, Talour K, Misery L. Itch Characteristics in Five Dermatoses: NonAtopic Eczema, Atopic Dermatitis, Urticaria, Psoriasis and Scabies. Acta Derm Venereol. 2013;93(5):573-4.

11. Brenaut E, Marcorelles P, Genestet S, Ménard D, Misery L. Pruritus: an underrecognized symptom of small-fiber neuropathies. J Am Acad Dermatol. 2015;72(2):328-32.

12. Elman S, Hynan LS, Gabriel V, Mayo MJ. The 5-D itch scale: a new measure of pruritus. Br J Dermatol. 2010;162(3):587-93. 
13. Desai NS, Poindexter GB, Monthrope YM, Bendeck SE, Swerlick RA, Chen SC. A pilot quality-of-life instrument for pruritus. J Am Acad Dermatol. 2008;59(2):234-44.

14. Plewig N, Ofenloch R, Mettang T, Weisshaar E. The Course of Chronic Itch in Hemodialysis Patients: Results of a 4-year Follow-Up Study of GEHIS (German Epidemiological Hemodialysis Itch Study). J Eur Acad Dermatol Venereol. 2019;33(7):1429-1435. 
Table I. Demographic and clinical baseline characteristics of patients with monoclonal gammopathy (MG) and controls and a comparison of features in cases with or without chronic pruritus (CP).

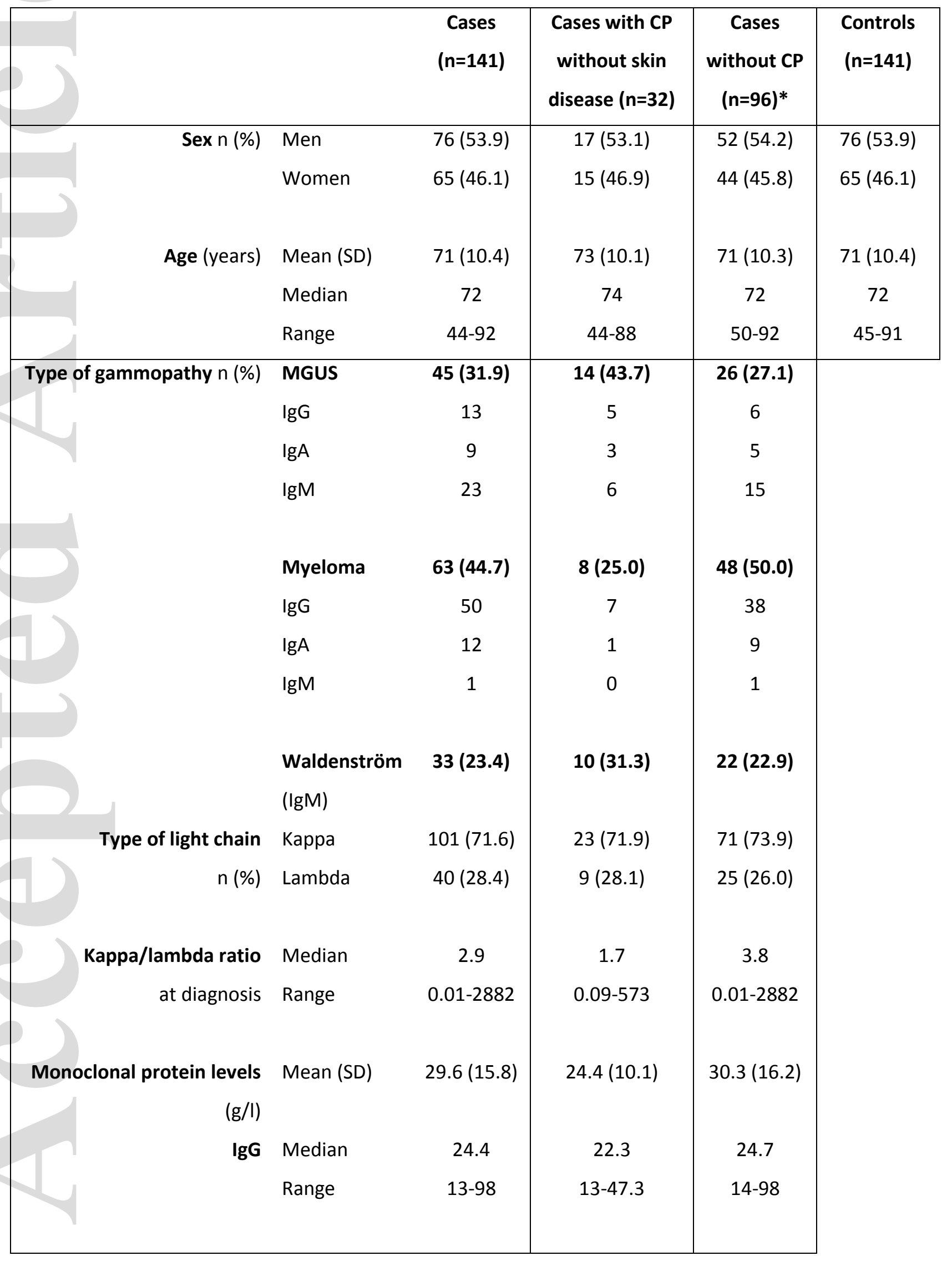




\begin{tabular}{|rlc|c|c|}
\hline IgA & Mean (SD) & $18.5(7.4)$ & $12.6(2.6)$ & $21.2(7.3)$ \\
& Median & 17 & 11.4 & 21.3 \\
& Range & $7.0-31.5$ & $10.6-17$ & $10.2-31.5$ \\
& & & & \\
IgM & Mean (SD) & $16.5(11.2)$ & $15.9(10.2)$ & $16.8(11.8)$ \\
& Median & 14.2 & 15 & 13.9 \\
& Range & $3.4-68$ & $3.4-39.1$ & $4.5-68$ \\
& & & & \\
& & $17(12.2)$ & $6(18.8)$ & $10(10.4)$ \\
Diagnosis of an MG & $<1$ year & $67(47.8)$ & $15(46.9)$ & $51(53.1)$ \\
& $1-5$ years & $7(21.9)$ & $21(21.9)$ \\
& $6-10$ years & $37(26.4)$ & $4(12.4)$ & $14(14.6)$ \\
& $>10$ years & $19(13.6)$ & 0 & 0 \\
\hline & Missing value & 1 & 0 & \\
\hline
\end{tabular}

MGUS: Monoclonal gammopathy of undetermined significance.

* Patients who had had pruritus and patients with CP with skin disease were excluded. 
Table II. Factors associated with the presence of pruritus in monoclonal gammapathies. Univariate and multivariate logistic regression models were used to assess the association of covariates with the presence of pruritus. The covariates examined were sex, age, the type of gammopathy, the type of heavy chain, the type of light chain, heavy chain levels at diagnosis, and the kappa/lambda ratio at diagnosis. An adjustment on age and sex was then added because of a known association with pruritus.

\begin{tabular}{|c|c|c|}
\hline & Odds Ratio (95\% CI) & $p$-value \\
\hline \multicolumn{3}{|c|}{ Univariate logistic regression } \\
\hline Sex (male) & $0.96(0.43-2.16)$ & 0.92 \\
\hline Age & $1.02(0.98-1.06)$ & 0.41 \\
\hline \multicolumn{3}{|l|}{ Gammopathy } \\
\hline Myeloma & $0.31(0.11-0.82)$ & 0.02 \\
\hline Waldenström & $0.84(0.31-2.26)$ & 0.74 \\
\hline \multicolumn{3}{|l|}{ Heavy chain } \\
\hline $\lg G$ & $0.95(2.28-3.84)$ & 0.94 \\
\hline $\operatorname{lgM}$ & $1.47(0.45-5.81)$ & 0.54 \\
\hline Monoclonal protein levels & $0.97(0.93-1.002)$ & 0.10 \\
\hline Light chain lambda* & $1.11(0.44-2.67)$ & 0.82 \\
\hline Kappa/lambda ratio & $0.998(0.994-1.000)$ & 0.28 \\
\hline \multicolumn{3}{|c|}{ Multivariate logistic regression } \\
\hline Sex (male) & $0.96(0.41-2.27)$ & 0.93 \\
\hline Age & $1.01(0.97-1.06)$ & 0.61 \\
\hline \multicolumn{3}{|l|}{ Gammopathy } \\
\hline Myeloma & $0.31(0.11-0.83)$ & 0.02 \\
\hline Waldenström & $0.81(0.28-2.30)$ & 0.69 \\
\hline
\end{tabular}

* ref light chain kappa. 